\title{
履修履歴を用いた科目成績の推定方法と検証 \\ Predicting Grade in College Courses \\ Based on Users' Learning Histories and its Verification
}

\author{
堀幸雄 ${ }^{\dagger}$ \\ 西森友省 \\ 今井慈郎 \\ 中山 克 ${ }^{\dagger \dagger}$
}

Yukio HORI Yusei NISHIMORI Yoshiro IMAI Takashi NAKAYAMA

†香川大学総合情報センター

Information Technology Center, Kagawa University

干 760-0016 香川県高松市幸町 2-1

EMail: horiyuki@itc.kagawa-u.ac.jp

‡香川大学大学院工学研究科

Graduate School of Engineering, Kagawa University

干 761-0396 香川県高松市林町 2217-20

†神奈川大学理学部

Faculty of Science, Kanagawa University

干 259-1293 神奈川県平塚市土屋 2946

大学では多数の知識を学ぶことができるが, 膨大な開講科目からどれが自分に向いているのかを知るの は困難である . 本研究は学生の科目履修履歴と成績が，これから履修する科目の成績にどのような影響が あるのかを調べ，今後履修する科目の成績の推定に利用可能であるかどうかについて考察した . 学生の科 目履修履歴と成績には分野ごとの特徵があり，履修履歴から今後受ける科目の成績を推定することが可能で あることがわかった.

In this paper, we analyzed grades in college courses to investigate whether users' learning histories and its grade score affected their future selection of courses and its grade score. We examine whether the histories are available to predict their future grade automatically. We extracted some features from the learning histories of the students. Then, we carried out a preliminary experiment to examine wheher it is able to predict grade score of courses from the learning histories. We found that students' learning histories and grade score could be used for predicting grade score effectively.

キーワード：時間割, シラバス，履修履歴，成績予測

\section{1 はじめに}

大学における留年者数の全学生に占める割合であ る留年率は, 1988 年度から増加傾向を示し, 2002 年度には全国 89 の国立大学において留年者率が $6.49 \%$ となっている ${ }^{[1]} .2002$ 年度以降男子学生に おける留年者率は減少しているが, 女子学生につい ての留年者率は増加傾向であることが分かっており， 留年学生に対するサポートや学生を留年させない取 り組みが必要であると考えられる.

学生にとって大学のカリキュラムを学んでいく上 で自分の得意不得意分野を知ることは重要であると 考えられる. 学生は自分の能力に適していない授業
科目を履修してしまうと, 単位を取得できなかった り, 授業科目の内容を充分に理解できず留年したり, 進級や就職活動などに不利になると考えられる . シ ラバスは大学の授業科目の多樣化や日々進歩する技 術に対応するため年々内容か変化し, まだ専門知識 がない学生や開講されている授業科目を熟知してい ない学生にとってはシラバスを閲覧するだけでは開 講されている授業科目の内容を把握しきれず, 学生 の能力に適した時間割を作成することは非常に困難 であると考えられる.

多くの大学では専門委員が新入生に対して修学に ついて相談を受けるアドバイザー制度を設けている. この制度では学生が直接アドバイスを受けることが 
できるが, 学生と専門委員共に時間や労力がかかり， また効果も一定ではないといった問題がある.

我々は, 学生の履修履歴から今後履修可能な科目 の成績を推定する手法を提案する . 本提案手法は履 修履歴に含まれる科目と今後履修可能な科目との関 連性，光して履修履歴中の科目の成績を用いて計算 される.これにより，学生は今後受ける科目につい て自身の得意不得意分野を反映した時間割を作成し， 学生に効率良く学習させることで学生の留年率の減 少や学生の授業科目の内容への理解を支援すること が可能になると考えられる.

本稿では本システムの提案手法, 及び評価実験を 行った結果について述べる. 以下, 2 章では本研究 の問題の所在を明確化するために, 先行研究につい て述べる. 3 章では本提案手法の詳細について述べ る. 4 章では実際のシラバス, 及び学生の時間割を 用いて, 本システムの有効性の評価を行う. 5 章は 結論であり, 今後の課題をまとめる.

\section{2 関連研究}

由谷らは，電子シラバスに現れる用語などを用 いた教養教育のカリキュラム分析を行っている ${ }^{[2] .}$ HTML 形式で記述されているシラバスを NIADUE が開発しているシラバス XML スキーマを用い てXML に変換し, シラバス項目で科目の情報が主 に記されている項目から名詞と关の複合語を抽出し， これらをキーワードと位置付けている. 光して一科 目を構築する文字列におけるキーワードが出現する 回数などに基づいてキーワードに重みを与えている. これにより科目の内容を,キーワードの重みを成分 とする一つのベクトルとして表現し, 科目間の類似 度を二つの科目のコサイン類似度を用いることで表 現している. さらにこの科目シラバス同士の関連性 の分析を行ない, 教員向けに独創的なカリキュラム の設計を支援する研究がある ${ }^{[3]}$.これら研究では, コサイン類似度を用いて科目間の類似度を算出して いる点では本研究と同じであるが, 本研究では学生 の履修履歴を元に個々の学生の得意分野や不得意分 野を推定し，今後履修可能な科目の成績を推定する という点が異なる。

高橋らは, フィルタリング技術を活用したシステ ム Airs (An Individual Reviewing System) を構築 している ${ }^{[4]}$. Airs は e-Learning 教育において, 提
供されるコンテンツがどの学習者に対しても同一の 内容の教材コンテンツを使用するため, 学習者の学 習レベルによって, 学習者の感じる難易度の差異が 出てきてしまう問題を解決するために構築されてい る. Airs では協調フィルタリングを活用することで, 学習者の学習履歴データを光の学習者の特徵データ としてデータベースに保存し, 他の類似している特 徵データを持つ学習者と比較することで, 光の学習 者の特徵を推測している. 同樣に e-Learning コン テンツの問題の回答状況から学習者の得意分野, 不 得意分野を推定するという研究も存在する ${ }^{[5]}$. これ ら研究では, 独自に開発した e-Learning コンテンツ の利用状況を元にユーザの特徵を分析しているが， 我々は科目シラバスという全科目に共通なデータと 成績を利用している点が異なる.

zhang らは大学における学生の授業選択支援を目 的として，授業間関係視覚化システムを開発してい る ${ }^{[6]}$.このシステムでは縦軸を配当学年, 横軸を分 野とする二次元平面上に, 授業をノード，授業間の 前提・発展関係を辺としたグラフを作成し，授業間 関係を表現する．このシステムにより学生は, 授業 間の関係を視覚的に概観でき，目的に沿った効率的 な授業選択が行なえるものである .この研究では， どの多数ある科目からどの分野に進むかというとい う俯瞰図を知ることができるが，学生の得意分野， 不得意分野という点は考慮していない .

我々は, Active Syllabus という活性伝播モデル ${ }^{[8]}$ を利用した時間割自動作成システムを開発している [7]. Active Syllabus は時間割作成を制約充足問題 に帰着し, 学生の興味をシラバス閲覧履歴などから ユーザプロファイルとして作成し，興味を最大に満 たす時間割を自動作成するものである (図 1).

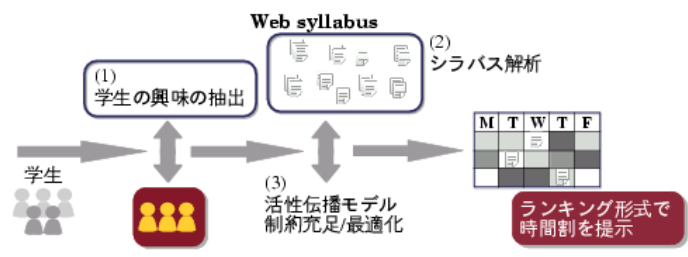

図 1: Active Syllabus の概要

Active Syllabus は图 2 に示すように科目間ネッ トワークの活性状態に着目し，科目シラバスに含 まれる単語の活性状態をスケジューリング問題の目 的関数に用いることで学生の興味に直接マッチして 


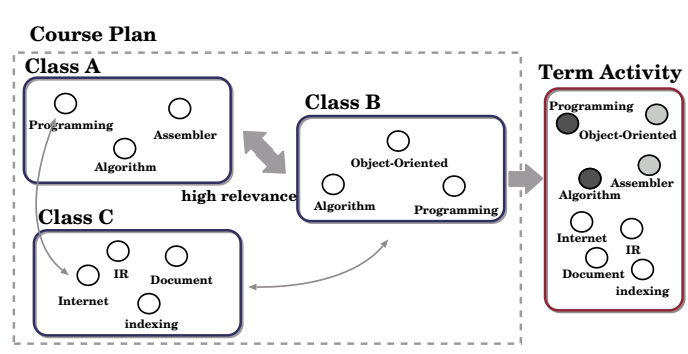

図 2: 科目間ネットワークにおける活性伝播モデル

いない授業科目を時間割に含めることができる. 時 間割作成のスケジューリング問題を解くための探索 手法として, ユーザプロファイルに適合する科目群 より初期解を求め, 兴の後反復改善法を初期解に適 用するというヒューリスティック探索を用いている. Active Syllabus では学生の興味を満たすという点 のみを考慮していたため, 学生の得意不得意分野を 考慮しておらず, 提案手法は学生の履修履歴から得 意不得意の推定を行なう点が異なる.

\section{3 提案手法}

提案手法は , 学生の履修履歴と科目の難易度を用 いて，履修可能な科目の成績の予測値を計算する． 提案手法は, 科目分析ステップ, 科目成績推定ステッ プの 2 つで構成される .

\section{1 科目分析}

大学で開講されている授業科目のシラバスデータ をWEB 上で公開されているシラバスから取得する. WEB 上で公開されているシラバスから, 対象学科, 年次, 区分, 授業科目, 科目コード, 科目区分, 科目 区分 (種類), 教員名, 学期, 曜日, 校時, 単位数, 授業 の目標, 授業の概要, 授業の方法, 成績の評価, 受講 上の注意, 授業計画, 教科書, 参考書, 質問の受付に 関してのテキストデータを抽出する.

各シラバスに出現する単語を形態素解析を用いて 抽出し, 产の出現頻度により, 授業科目 $c_{i}$ のシラバ スの文書べクトルを作成する. 1 つの授業科目 $c_{i}$ に 出現する単語を tf-idfにより重み付けを行い, $c_{i}$ を 次のように表わした.

$$
\begin{aligned}
& c_{i}=\left(\omega_{i 1}, \omega_{i 2}, \ldots, \omega_{i n}\right) \\
& \omega_{i, t j}=t f\left(t_{j}, c_{i}\right) i d f\left(t_{j}\right)
\end{aligned}
$$

$$
i d f\left(t_{j}\right)=\log \left(N / d f\left(t_{j}\right)\right)
$$

ただし, $t f\left(t_{j}, c_{j}\right)$ は授業科目シラバス $c_{i}$ における 単語 $t_{j}$ の出現頻度であり, $N$ は総科目数, $d f\left(t_{j}\right)$ は 単語 $t_{j}$ が 1 回以上出現する科目数である.

今回我々の所属する科目シラバスデータの香川大 学全学共通科目の出現単語数は 17,168 個, 信頼性 情報システム工学科の出現単語数は 8,878 個であつ た. また，下記の単語は除外した.

- 名詞の数, 接続, 記号

・ひらがな, カタカナ, アルファベット 1 文字の 単語, これらは形態素解析に失敗している可 能性が高いため除外した.

本手法では類似度を算出するためにベクトル空間 におけるコサイン類似度を用いた. コサイン類似度 を用いて科目間の類似度は式 (1) より算出される.

$$
L_{i j}=\frac{c_{i} c_{j}}{\left\|c_{i}\right\|\left\|c_{j}\right\|}=\frac{\sum_{k=1}^{N} \omega_{i k} \omega_{j k}}{\sqrt{\sum_{k=1}^{N} \omega_{i k}^{2}} \sqrt{\sum_{k=1}^{N} \omega_{j k}^{2}}}
$$

\section{2 科目成績推定}

提案手法は履修可能な授業科目と学生が過去に履 修した授業科目との類似度，およびその科目の成績 を用いて成績を推定する．履修済みの成績には表 1 の通りの 5 段階の評価による重みを付けた .

\begin{tabular}{c|c|c}
\multicolumn{3}{c}{ 表 1: 成績評価による重み } \\
\hline \hline 成績 & 評点 & 重み \\
\hline 秀 & 90 点以上 & 4 \\
\hline 優 & 90 点未満 & 3 \\
\hline 良 & 80 点未満 & 2 \\
\hline 可 & 70 点未満 & 1 \\
\hline 不可 (放棄) & 60 点末満 & 0 \\
\hline
\end{tabular}

履修可能な科目 $c_{t}$ の成績の推定値 $\operatorname{Score}\left(c_{t}\right)$ は 式 (3) による算出する. $\operatorname{Score}\left(c_{t}\right)$ は, $0-4$ までの 值を取るものであり，この值を成績の推定値とする． $\operatorname{GPA}\left(c_{i}\right)$ の值は成績に応じて表 1 の值を取る.$N$ は履修履歴に含まれる科目数を示す. 


$$
\begin{aligned}
\operatorname{Prob}\left(c_{t}, i\right) & =\frac{L_{c_{t} c_{i}}}{\sum_{i=1}^{N} L_{c_{t} c_{i}}} \\
\operatorname{Score}\left(c_{t}\right) & =\sum_{i=1}^{N} \operatorname{GPA}\left(c_{i}\right) \operatorname{Prob}\left(c_{t}, c_{i}\right)
\end{aligned}
$$

\section{3 成績推定の例}

成績推定の実際の例として，ある学生の 3 年前期 までの履修履歴を用いて, 3 年後期に開講されてい る科目 (表 2) の成績を推定した結果を表 3 に示す. 表 3 では, $\operatorname{Score}\left(c_{t}\right)$ の值が 2 末満のものを不得 意科目， 2 以上のものを得意科目として表記した .

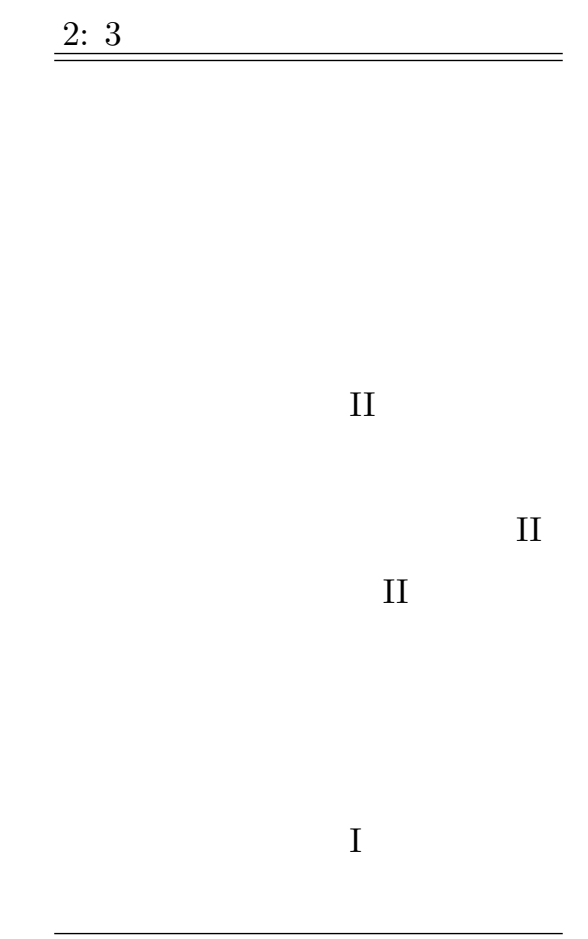

\begin{tabular}{c|c}
\multicolumn{2}{c}{ 表 3: 成績推定の例 } \\
\hline \hline 得意科目 & 信頼性数理 \\
& ソフトウェア工学 II \\
& 知識工学基礎 \\
\hline 不得意科目 & 情報通信システム I \\
& 計算機ネットワーク II \\
& 電波・光工学 \\
\hline
\end{tabular}

\section{4 評価実験}

本提案手法の有効性を調べるために実際の学生の 履修情報を用いて，推定した成績と実際の成績との 平均絶対誤差を算出した。評価実験に用いたデータ を表 6 に示す.

\begin{tabular}{c|c}
\multicolumn{2}{c}{ 表 6: 実験データ } \\
\hline \hline 所属 & $\begin{array}{c}\text { 香川大学工学部 } \\
\text { 信頼性情報システム工学科 }\end{array}$ \\
\hline 学年 & 1 年後期 -3 年後期 \\
\hline 人数 & 8 名 \\
\hline シラバス & 2009 年度 \\
\hline 対象科目数 & 595 科目 \\
\hline 推定科目数 & 340 科目 \\
\hline
\end{tabular}

本提案手法により推定した場合の平均絶対誤差を 表 4，0-4 までの成績の推定值をランダムに推定し た場合の平均絶対誤差を表 5 に示す . ランダムに推 定した場合は, 約 1.5 程度の差があるが, 本提案手 法で推定した場合には約 1.0 程度の差で成績を推 定できる .

また科目の難易度, 履修科目のなかで最も類似し ている科目の成績を推定値と提案手法を比較したも のを図 3 に示す.ここで科目の難易度を用いた推 定は, 科目ごとの不合格率に応じて成績を推定する 手法である.この場合，不合格率が 0.2 未満のとき 秀, 0.4 未満のとき優, 0.6 未満のとき良, 0.8 未満 のとき可，0.8以上のときに不可と成績を推定する 図 3 より, 提案手法, 最も類似している科目科目の 難易度，無作為による推定の順で平均絶対誤差が小 さいことがわかった . 最も類似している科目による 推定が評価が良いのは，履修履歴が増えてくると， 提案手法ではあまり関連のない科目が履修履歴に含 まれている場合に乥の影響を受けてしまい推定が正 しく行なえないためだと考えられる．

\section{5 おわりに}

本稿は 学生の履修履歴から学生の得意, 不得意分 野を推定し，今後履修可能な科目の成績を推定する 手法について述べた . 成績の推定に, 科目の難易度 
表 4: 提案手法により推定した場合の平均絶対誤差

\begin{tabular}{c|c|c|c|c|c}
\hline \hline & 1 年後期 & 2 年前期 & 2 年後期 & 3 年前期 & 3 年後期 \\
\hline 学生 1 & 0.38 & 0.80 & 1.30 & 0.89 & 1.00 \\
\hline 学生 2 & 0.63 & 1.00 & 1.20 & 1.11 & 0.78 \\
\hline 学生 3 & 1.00 & 0.80 & 1.00 & 1.17 & 0.67 \\
\hline 学生 4 & 0.83 & 0.50 & 0.63 & 1.20 & 0.80 \\
\hline 学生 5 & 0.71 & 0.60 & 0.80 & 1.20 & 1.30 \\
\hline 学生 6 & 0.50 & 0.20 & 0.70 & 0.69 & 0.33 \\
\hline 学生 7 & 1.14 & 0.40 & 1.10 & 0.63 & 0.89 \\
\hline 学生 8 & 1.13 & 1.00 & 1.70 & 1.11 & 0.57 \\
\hline
\end{tabular}

表 5: 無作為に推定した場合の平均絶対誤差

\begin{tabular}{c|c|c|c|c|c}
\hline \hline & 1 年後期 & 2 年前期 & 2 年後期 & 3 年前期 & 3 年後期 \\
\hline 学生 1 & 1.63 & 1.20 & 1.60 & 2.00 & 1.73 \\
\hline 学生 2 & 1.53 & 1.40 & 1.40 & 1.78 & 1.56 \\
\hline 学生 3 & 1.13 & 2.20 & 1.10 & 0.92 & 2.44 \\
\hline 学生 4 & 1.33 & 2.00 & 1.38 & 1.60 & 1.40 \\
\hline 学生 5 & 1.43 & 1.00 & 1.20 & 1.70 & 1.80 \\
\hline 学生 6 & 1.38 & 1.60 & 1.40 & 1.31 & 2.11 \\
\hline 学生 7 & 2.14 & 1.00 & 1.70 & 1.63 & 1.22 \\
\hline 学生 8 & 1.50 & 2.00 & 1.50 & 2.22 & 1.57 \\
\hline
\end{tabular}

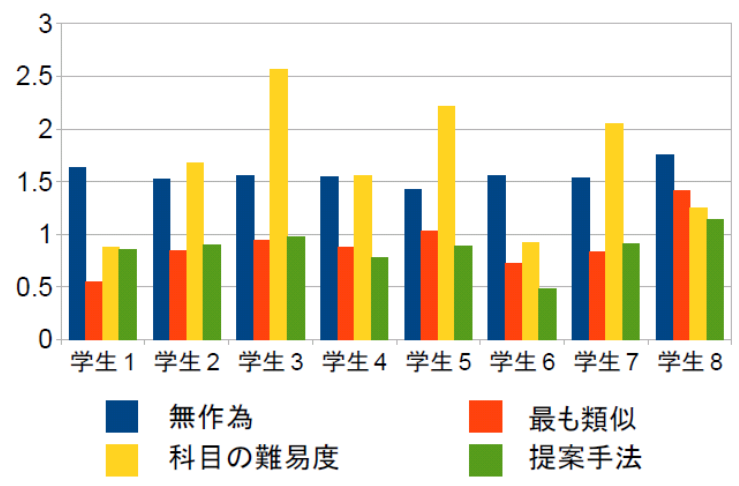

図 3: 各手法ごとの MAE

だけでなく学生のこれまで履修した科目の成績を考 慮することで, 他の推定手法に比べて高く精度で成 績を推定できることがわかった .ただし，学部 1 年 次においては履歴が十分でないので, このような場
合には履修履歴を用いずに科目の難易度を用いて成 績の推定を行なうといったことが考えられる．

今後の課題として, 提案した学生の成績の推定方 法を元に学生に得意分野や不得意分野といった点を 考慮した時間割を作成すること，また工学部カリ キュラムだけでなく他学部他学科の学生を対象に評 価実験を行い，他学部他学科のデータおける本提案 手法の有効性を確認することである.

\section{謝辞}

本研究の一部は 2012 年度 IPA 情報処理推進機 構未踏 IT 人材発掘・育成事業の支援を受けて行わ れています． 


\section{参考文献}

[1] 内田千代子: 大学における休・退学, 留年学生 に関する調査 第 27 報, 全国大学メンタルヘル 不研究会報告書 第 28 回 ; 13-25，2007.

[2] 由谷真之; 森幹彦; 喜多一: 電子シラバスを用い た大学教養教育のカリキュラム分析, 情報科学 技術フォーラム一般講演論文集 4(4), 315-316, 2005.

[3] 野澤 孝之, 井田 正明, 芳鐘 冬樹, 宮崎 和光, 喜 多一: シラバスの文書クラスタリングに基づ くカリキュラム分析システムの構筑, 情報処理 学会論文誌, Vol.46, No.1, pp.289-300, 2005.

[4] 高橋泰樹; 松澤俊典; 山口未来; 土肥紳一; 和田 雄次: 履歴データを活用した教育支援システム Airs, 情報科学技術フォーラム一般講演論文集 5(4), 367-368, 2006.

[5] 佐藤 彰紀, 上之薗 和宏, 橋立 真理恵, 古宮 誠 一: 設問の難易度を導入し学習者の不得意分野 を客観的に同定する CAI システム，電子情報 通信学会, 信学技研 ET Vol. 109, No. 335, pp. 55-60, 2009.

[6] ZHANG Jingjing, 森田 卓巳, 井上智雄, 横山 節 雄, 宮寺 庸造: 授業間関係視覚化システム, 電子 情報通信学会, 信学技研, ET Vol.103, No.697, pp. 185-190, 2004.

[7] 堀 幸雄; 中山 堯; 今井 慈郎: 科目ネットワー ク上の活性伝播を用いた時間割の自動生成シ ステム，情報処理学会論文誌, Vol.52, No.7, pp.2332-2342, 2011.

[8] J.R. Anderson: A spreading activation theory of memory, Journal of Verbal Learning and Verbal Behavior, 22, pp.261-295, 1983. 